\title{
Os cinco anos de produção científica marcam o início de uma nova história
}

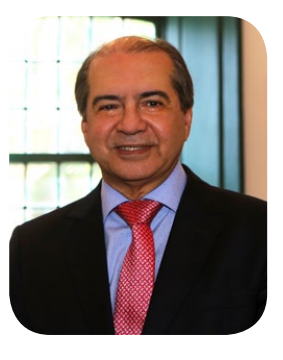

Quando iniciamos a jornada da produção científica no Hospital Santa Izabel, em 2014, nossa intenção era fomentar nos profissionais o interesse na área, com expansão do número de estudos e pesquisas realizados internamente. Cinco anos depois, percebemos que essa jornada nos levou muito além. Foram aproximadamente 200 artigos produzidos e publicados em 20 edições trimestrais impressas ininterruptamente.

Ao longo deste período, foram realizadas algumas adaptações, como a mudança do nome da revista e de seu aspecto visual. É como um filho que cresce e vai amadurecendo, tomando forma, ganhando corpo e visibilidade. O sucesso dessa publicação, que já extrapolou os muros deste hospital, deve-se muito à atuação e dedicação pessoal de Dr. Gilson Soares Feitosa, diretor de Ensino e Pesquisa do HSI. Ele e sua equipe se dedicam com muito afinco em todos os detalhes que envolvem essa produção.

A

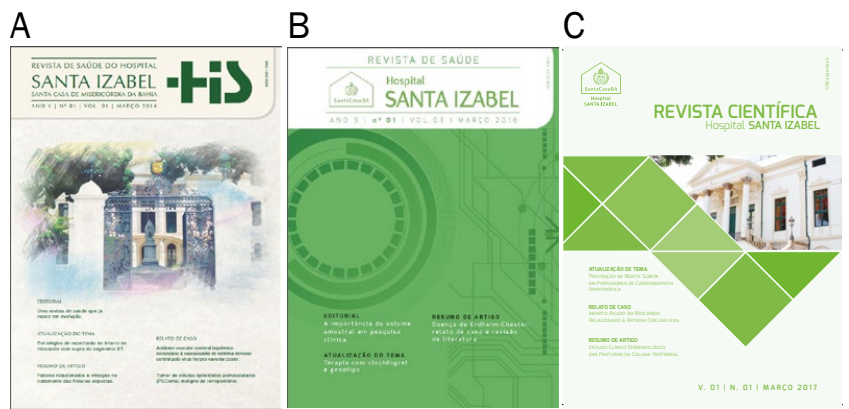

Figura 1 - (A) Capa da primeira revista, em 2014.

(B) Primeira mudança no projeto gráfico. (C) Novo leiaute, mais leve e moderno.

Assim como eu escrevi na primeira edição, reafirmo a contribuição dos estudos aqui publicados para a construção de um ambiente de inquietação intelectual, como deve ser uma instituição que preza pela

\author{
Roberto Sá Menezes ${ }^{1}$
}

formação, profissionalização e atualização de profissionais qualificados na área de saúde. A Santa Casa da Bahia orgulha-se em manter, desde 1549 , seu pioneirismo e sua incansável dedicação para subsidiar avanços importantes na medicina do nosso estado.

A celebração pelos cinco anos da Revista Científica também marca o início de uma nova história desta publicação. Já estamos em processo para uma mudança significativa, que busca atender os critérios necessários para a indexação da revista em nível internacional. Isso fará com que o conhecimento seja melhor disseminado e passe a ficar mais acessível, de forma rápida e sistemática, o que terá como resultado uma maior visibilidade das produções. A indexação de um periódico em bases de dados é importante para ampliar o reconhecimento da comunidade médica e científica, com aval à qualidade de seus artigos, além de comunicar e tornar públicos o debate e os avanços da ciência.

Que venham as mudanças! Boa leitura.

1- Provedor da Santa Casa da Bahia
Endereço para correspondência:
provedoria@santacasaba.org.br

